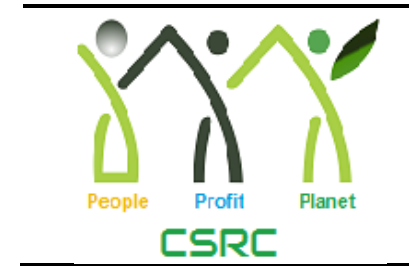

Volume and Issues Obtainable at Center for Sustainability Research and Consultancy

Journal of Accounting and Finance in Emerging Economies

ISSN: 2519-0318 ISSN (E) 2518-8488

Volume 6: Issue 3 September 2020

Journal homepage: www.publishing.globalcsrc.org/jafee

\title{
Interest Rate Spread and the Efficacy of Commercial Banks' Loans and Advances in Nigeria
}

\author{
${ }^{1}$ Efanga, Udeme Okon, ${ }^{2}$ Ihemeje, J. C, ${ }^{3}$ Yamta H. A, ${ }^{4}$ Biradawa Kayadi \\ ${ }^{1}$ Department of Banking and Finance, Faculty of Management Sciences, University of Calabar, Nigeria, \\ udemeefanga@gmail.com \\ ${ }^{2}$ College of Management Sciences, Michael Okpara University, Umudike, Nigeria \\ ${ }^{3 \& 4}$ Department of Banking and Finance, University of Maiduguri, Nigeria
}

\begin{tabular}{l}
\hline ARTICLE DETAILS \\
\hline History \\
Revised format: August 2020 \\
Available Online: September 2020 \\
\hline Keywords \\
Loans and advances of commercial \\
banks', interest rate spread, liquidity \\
ratio, monetary policy rate, \\
exchange rate and inflation rate
\end{tabular}

JEL Classification

M40, M41

\section{OPEN ACCESS}

\section{ABSTRACT}

The cardinal objective of this research is to analyze the impact of interest rate spread on the efficacy of commercial banks' lending in Nigeria. Data employed in this study were elicited from Central Bank of Nigeria Statistical bulletin, 2018 and International Monetary Fund, International Financial Statistics and data files. Unit root test result showed that the variables were integration of 1(0) and 1(1), the Autoregressive Distributed Lag (ARDL) Model was employed to analyze data. Several diagnostic tests were carried out and they all confirmed the goodness of fit and validity of the model employed. The findings elicited from this study showed that: commercial banks' loans and advances responded positively and significantly to the impact of interest rate spread in Nigeria. The study concludes that interest rate spread had a positive impact on loans and advances of commercial banks' within the scope of this study. The study recommend that commercial banks in Nigeria should maintain their current interest rate spread strategy, since it is yielding profit and helping them realize a high demand for their loans and advances in Nigeria.

(C) 2020 The authors, under a Creative Commons AttributionNonCommercial 4.0

Corresponding author's email address: udemeefanga@gmail.com

Recommended citation: Okon, E. U., Themeje, J. C., Yamta, H.A., \& Keyadi, B. (2020). Interest Rate Spread and the Efficacy of Commercial Banks' Loans and Advances in Nigeria. Journal of Accounting and Finance in Emerging Economies, 6(3), 753-763

\section{Introduction}

The cardinal objective of commercial banks in any economy is financial intermediation. That is, the facilitation of the channeling of funds from surplus economic unit to deficit economic unit. Financial intermediation is enhanced if a higher percentage of the population in a financial system is included financially. Financial inclusion brings so many prospective banks' customer into the banking net and enable commercial banks realize more customers which would ultimately lead to increase liquidity for the banks for on lending to borrowers seeking out loan facilities. Depositors are paid certain rate to encourage them to save their money with the banks and such saved funds are lend out to investors for a higher interest rate than that paid to the depositors.

The difference arrived at when you deduct lending rate from deposit rate is what is referred to as interest rate spread. Interest rate spread is that figure arrived at once you deduct the rate of interest charged to borrowers from that rate of 
interest which is paid to depositors (Maureen and Joseph, 2014). Efficient financial intermediation is achieved when the depositor or saver receives the highest expected return for his savings while also providing funds for borrowers or investors at the lowest interest rate possible. When efficient intermediation is arrived at in the economy, this will be highly beneficial to the real economy since it will bring about enhanced or higher streams of income to the savers (depositors) and in the same time, provide investible funds for an optimal interest rate. (Quaden, 2004).

Akmal, Khalid and Muhammad (2012) opined that higher interest rate spread discourages potential savers and is an obstacle for a prospective investor; since the cost of intermediation between the saver and the investor have strong correlation and synergy in financial intermediation and capital mobilization. Inefficiencies associated with financial intermediation causes higher intermediation cost and increase loss of productive funs in the process of intermediation, this will further culminate to loss in savings, lending and profitability of the banks and by extension economic growth and development in that economy.

However, (Dollente, 2005) opined that high interest rate spread shows the problem in the regulatory institutions or agencies of banks and information asymmetry. According to him, higher interest rate can improve profitability of banking system. (Nazarian and Hashumi 2010) argued that high interest spread can be said to be as a result of inefficiency or reduced efficiency of the banking system and lack of competition in the market for investors seeking for funds to borrow and savers seeking out borrowers. On the other hand, they agreed with the assertion of (Dollente, 2005) that high amount of the variable indicates inadequate regulation, lack of depth in the financial system and a high level of information asymmetry.

Several authors have disclosed above have taken different positions either in support or in negation that high interest rate spread leads to profitability of the banks. It is against this backdrop that this study attempts to analyze the impact of interest rate spread on commercial banks' loans and advances in the Nigerian financial system.

\subsection{Hypotheses}

$\mathrm{HO}_{1}$ : There is no significant impact of interest rate spread on commercial banks' loans and advances in Nigeria.

$\mathrm{HO}_{2}$ : There is no significant impact of monetary policy rate on commercial banks' loans and advances in Nigeria.

$\mathrm{H}_{3}$ : There is no significant impact of statutory reserve on commercial banks' loans and advances in Nigeria.

$\mathrm{HO}_{4}$ : Inflation rate has no significant impact on commercial banks' loans and advances in the Nigerian financial system.

$\mathrm{H}_{5}$ : There is no significant impact of exchange rate on commercial banks' loans and advances in Nigeria.

\section{Literature Review}

\section{Conceptual Review - Factors that Influences Interest Rate Spread}

\subsection{Legal Reserves}

the major commodity of commercial banks is money, the trade money to make profit in form of loans to investors. Legal or statutory reserve influences interest rate spread in the sense that commercial banks are by law required to keep some percentage of their deposits with the central bank; that proportion of funds tight down in the vault of the central bank would have been utilized for on lending to investors. When the reserve ratios are increased, the banks are left with fewer funds to lend to investors which will in turn increase interest rate spread.

\subsection{Bank Performance}

the performance of a bank can determine its interest rate spread, a commercial bank that has lots of customers that are repaying their loans and advances as at when due, won't have problem of reducing its interest rate spread since the bank is doing well, but in a situation where a bank is not doing well and their stock of bad debt is piling up, such bank won't have any reason to reduce their interest rate spread, instead their spread would be on the increase in order to cover up lost funds.

\subsection{Inflation Rate}

the rate of inflation in the financial system is capable of influencing interest rate spread; this is so because once there is inflation, there is a sharp drop in the value of money in circulation in that economy. There fore, commercial banks 
will increase the lending rate which will in turn increase interest rate spread so as to meet up the value of the declining currency in circulation.

\section{Empirical Review}

Varaldzo and Asiat (2018) in their paper captioned the impact of interest rate spread on the banking system efficiency in South Africa; the researchers utilized total banking asset as the dependent variable while gross domestic product (GDP), interest rate spread, non-performing loans and real exchange rate (ZAR/US\$) as the explanatory variables. This study used Nonlinear Auto Regressive Distributed Lag Model (NARDL) approach was adopted and their findings revealed that non-performing loans was significant in reducing the effectiveness of the South African banking system while interest rate spread has a negative and significant impact on banking system efficacy in South Africa.

In another study, Muine and Essau (2012) under took a study titled Determinants of commercial banks' interest rate spread in Namibia. This study employed a panel data analysis approach and used ordinary least squares regression technique to analyze data between 2004 and 2011. Net interest margin (NIM) was employed as the explained variable while liquidity ratio, non-performing loans, banks' core capital, tax paid by commercial banks and deposit market shares were utilized as independent variables. The study deduced that deposit market share and cost efficacy ratio narrow interest rate spread.

In a similar study, Arezoo and Malihe (2016) studied the determinant of interest rate spread in banking industry in Iran. The authors identified non-performing loans, demand deposit, non-interest income and capital adequacy ratio as the core determinants of interest rate spread and concluded that all the above mentioned variables were significant in influencing interest rate spread in the Iran financial system. However, limited attention has been focused on the empirical understanding of the impact of interest rate spread on commercial banks' lending efficacy in the Nigeria banking system.

Felix, Ihuoma and Odim (2015) employed the classical least squares method for their study and examined empirically the effect of interest rate deregulation on commercial banks' lending operations in Nigeria from 1970 to 2013 . The researchers divided the period of study into two; the period that interest rate was regulated spanning from 1970 to 1986 and another period where interest rate was not regulated spanning from 1987to 1986. The Chow test was utilized to analyze to ascertain if there exist a significant change in the relationship that existed between interest rate for the two periods earlier mentioned and commercial banks' lending in the Nigerian financial system. The empirical result elicited from this study from the interest rate regulated era revealed that interest rate spread recorded a significant and negative effect on the volume of commercial banks' loans, while for the deregulation era, the result further revealed that interest rate spread was found to be positive and significantly impacted on commercial banks' loans and advances for the period.

\section{Methodology}

\subsection{Research Design}

The ex-post facto research design was adopted for this study since these types of research deals on events that had already taken place. As such, secondary data which were readily available we collected for analysis. The model adopted in this study was estimated using the Auto-Regressive Distributed Lag (ARDL) Model.

\subsection{Source of Data Collection}

In this study, data were elicited from Central Bank of Nigeria Statistical Bulletin of 2018 and International Monetary Fund, International Financial Statistics and data files. The study period covers 1981 through 2018.

\section{Method of Data Analysis}

This study utilized pre- estimation test, diagnostic tests and Auto Regressive Distributed Lag (ARDL) Model in testing hypotheses formulated for this study. The statistical package used for data analysis was E-view 9.0 version. 


\subsection{Model Specification}

This research utilizes a primary model formulated by the authors; the model for this research is built or structured to establish the functional relationship between interest rate spread and the efficacy of commercial banks lending in Nigeria, 1981 - 2018. The model tested in this study is a multiple regression model stated below:

LOGCBLA=F (IRS, MPR, SR, IFR, EXR)

By modifying the functional model in equation (1) into econometric model (semi-log):

LOGCBLA $=\beta_{0}+\beta_{1}$ IRSt $+\beta_{2}$ MPRt $+\beta_{3}$ SRt $+\beta_{4}$ IFR $t+\beta_{5}$ EXRt $+\mu_{\mathrm{t}}$

Where $\beta_{0}, \beta_{1}, \beta_{2}, \beta_{3}, \beta_{4}$ and $\beta_{5}$ are the parameters

CBLA $=$ Commercial banks' loans and advances in Nigeria

IRS = Interest rate spread (Lending rate - Deposit rate)

MPR = Monetary policy rate

$\mathrm{SR}=$ Statutory reserve (liquidity ratio)

$\mathrm{IFR}=$ Inflation rate

$\mathrm{EXR}=$ Exchange rate

$\mu_{\mathrm{t}}=$ Stochastic term

$\mathrm{LOG}=$ Natural logarithm

\subsection{A Priori Expected Results}

Interest rate spread is expected to have a negative impact on commercial banks' loans and advances in Nigeria. Monetary policy rate is expected to have a negative impact on commercial banks' loans and advances in Nigeria. Statutory reserve is expected to have a negative impact on commercial banks' loans and advances in Nigeria. Inflation rate is expected to have a negative impact on commercial banks' loans and advances in Nigeria. Exchange rate is expected to have a negative impact on commercial banks' loans and advances in Nigeria.

\section{Data Analysis and Results Interpretation}

\subsection{Pre-estimation Test Result (Unit Root Test)}

Unit root test was carried out to establish the order of integration. The results of the Augmented Dickey-Fuller based unit root test are as summarized in Table 1 below:

\begin{tabular}{llll} 
Variable & \multicolumn{2}{c}{ Table 1: Unit root test results } \\
LOG(CBLA) & $1.690842\{0.9994\}$ & $\begin{array}{c}\text { First difference } \\
\text { Order of integration }\end{array}$ \\
IRS & $-4.050866\{0.0033\}^{* * *}$ & $\mathrm{I}(1)$ \\
MPR & $-3.154500\{0.2256\}$ & $-6.380394\{0.0000\}^{* * *}$ & $\mathrm{I}(1)$ \\
\hline LR & $-3.589969\{0.0108\}^{* *}$ & $\mathrm{I}(0)$ \\
\hline IF & $-2.885282\{0.0567\}$ & $-5.592820\{0.0000\}^{* * *}$ & $\mathrm{I}(0)$ \\
\hline EXR & $1.335249\{0.9984\}$ & $-3.537770\{0.0125\}^{* *}$ & $\mathrm{I}(1)$ \\
\hline & Source: Author's analysis using e-view 9 output
\end{tabular}

Note: ** and $* * *$ denote significance @ 5\% and 1\% respectively

Figures in parenthesis \{\} denote the p-values

Based on the results of the Augmented Dickey-Fuller unit root test in Table 1, all the variables are integrated of order I(1) except MPR and LR which are integrated of order I(0). Being that the variables are of mixed integration, that is, I(0) and I(1), the Autoregressive Distribution Lag (ARDL) approach to ordinary least squares (OLS) was used for the empirical analysis.

\subsection{Descriptive Statistics}

Table 2: Descriptive statistics

\begin{tabular}{|l|c|c|c|c|c|c|}
\hline & CBLA & IRS & LR & MPR & IFR & EXR \\
\hline Mean & 3662.065 & 6.323158 & 46.87828 & 13.06579 & 19.33263 & 104.4552 \\
Median & 446.9264 & 6.960000 & 46.22500 & 13.25000 & 12.55000 & 111.1675 \\
Maximum & 16117.20 & 11.06000 & 65.10000 & 26.00000 & 72.84000 & 306.1000
\end{tabular}




Journal of Accounting and Finance in Emerging Economies
\begin{tabular}{|l|c|c|c|c|c|c|} 
Minimum & 8.582900 & 0.320000 & 29.10000 & 6.000000 & 5.380000 & 4.536700 \\
Std. Dev. & 5284.304 & 2.804789 & 9.691184 & 4.100381 & 17.25014 & 78.39935 \\
Skewness & 1.236060 & -0.591343 & 0.232822 & 0.669171 & 1.743174 & 0.719999 \\
Kurtosis & 3.088449 & 2.579050 & 2.459034 & 4.231054 & 4.839820 & 3.421495 \\
Jarque-Bera & 9.688733 & 2.495245 & 0.806658 & 5.235529 & 24.60431 & 3.564487 \\
Probability & 0.007873 & 0.287187 & 0.668092 & 0.072966 & 0.000005 & 0.168260 \\
Sum & 139158.5 & 240.2800 & 1781.374 & 496.5000 & 734.6400 & 3969.298 \\
Sum Sq. Dev. & $1.03 \mathrm{E}+09$ & 291.0732 & 3475.005 & 622.0855 & 11009.99 & 227418.9 \\
Observations & 38 & 38 & 38 & 38 & 38 & 38 \\
\hline
\end{tabular}

Source: Author's analysis using e-view 9 output

The table above presents the descriptive statistics of this study. The table shows that CBLA has the highest mean value of 3662.065, followed by EXR which has 104.4552, then LR with 46.87 while IFR, MPR and IRS have 19.33, 13.06 and 6.323 respectively. From the analysis, CBLA has the highest Standard Deviation as it recorded 5284.304, implying that it is the most volatile variable in the model as it has the highest percentage of dispersion from the mean. Four variables, IRS, LR, EXR and MPR with -0.591343, 0.232822, 0.719999 and 0.669171 respectively, are skewed a little to the left, while CBLA and IFR which have 1.236060 and 1.743 respectively are skewed to the right.

From Table 2 above, CBLA, MPR, IFR and EXR are peaked or leptokurtic because they have values of 3.08, 4.23, 4.83 and 3.42 respectively, while IRS and LR have a values of 2.57 and 2.45 are said to be flat or platykurtic.

It is important to note that although skewness and kurtosis points out the level of departure from normality, such positions are not concrete enough to discredit the overall goodness of fit of the dataset. The number of observation of 38 depicts the duration of the study.

\subsection{ARDL Model Result}

Table 3: ARDL Result

\begin{tabular}{cclrr}
\hline \hline Variable & Coefficient & Std. Error & t-Statistic & Prob.* \\
\hline \hline LOG(CBLA(-4)) & 0.320372 & 0.193278 & 1.657570 & 0.1213 \\
IRS(-2) & 0.063883 & 0.029121 & 2.193713 & 0.0470 \\
MPR(-4) & 0.037255 & 0.011624 & 3.204950 & 0.0069 \\
LR(-2) & -0.007669 & 0.007154 & -1.071918 & 0.3033 \\
IFR(-3) & -0.010299 & 0.003857 & -2.670071 & 0.0193 \\
EXR & -0.001053 & 0.001117 & -0.942444 & 0.3632 \\
C & 0.755930 & 0.892872 & 0.846627 & 0.4125 \\
\hline \hline R-squared & 0.998464 & Mean dependent var & 6.499280 \\
Adjusted R-squared & 0.996102 & S.D. dependent var & 2.484840 \\
S.E. of regression & 0.155148 & Akaike info criterion & -0.614990 \\
Sum squared resid & 0.312922 & Schwarz criterion & 0.327762 \\
Log likelihood & 31.45482 & Hannan-Quinn criter. & -0.293484 \\
F-statistic & 422.5910 & Durbin-Watson stat & 2.247067 \\
Prob(F-statistic) & 0.000000 & & \\
\hline \hline
\end{tabular}

Source: Author's analysis using e-view 9 output

From the ARDL Model result above in table 3, the result revealed that the R-squared was 99\%, this means that the independent variables accounted for about $99 \%$ variations in the dependent variable while the remaining $1 \%$ may be attributed to variables not included in the model. Put differently, all the independent or explanatory variables accounted for about $99 \%$ changes in commercial banks' loans and advances in Nigeria, while the remaining $1 \%$ could be attributed to stochastic term.

The result revealed that IRS had a positive and significant impact on CBLA such that a unit increase in IRS would bring about a 0.06 percent increase in CBLA. MPR had a positive and significant impact on CBLA such that a percentage increase in MPR would bring about a 0.03 percent increase in CBLA. LR recorded a negative and insignificant impact on CBLA such that a percentage increase in LR would bring about a 0.007 percent decrease in CBLA. IFR was found to have a significant negative impact on CBLA such that a unit increase in IFR would bring 
about a 0.01 percent decrease in CBLA. Furthermore, EXR was observed to record a negative yet insignificant impact on CBLA such that a unit increase in EXR would bring about a 0.01 percent decrease CBLA.

The result further revealed that the overall model was a good fit owing to the f-statistic value of 422.5910 and its corresponding p-value of 0.000000 which shows that the model is significant at $5 \%$ level of significance. Durbin Watson Statistic of 2.24 showed that the variables were free from auto-correlation since it is within the region of 2.

Figure 1: (Top 20 Models)

Akaike Information Criteria (top 20 models)

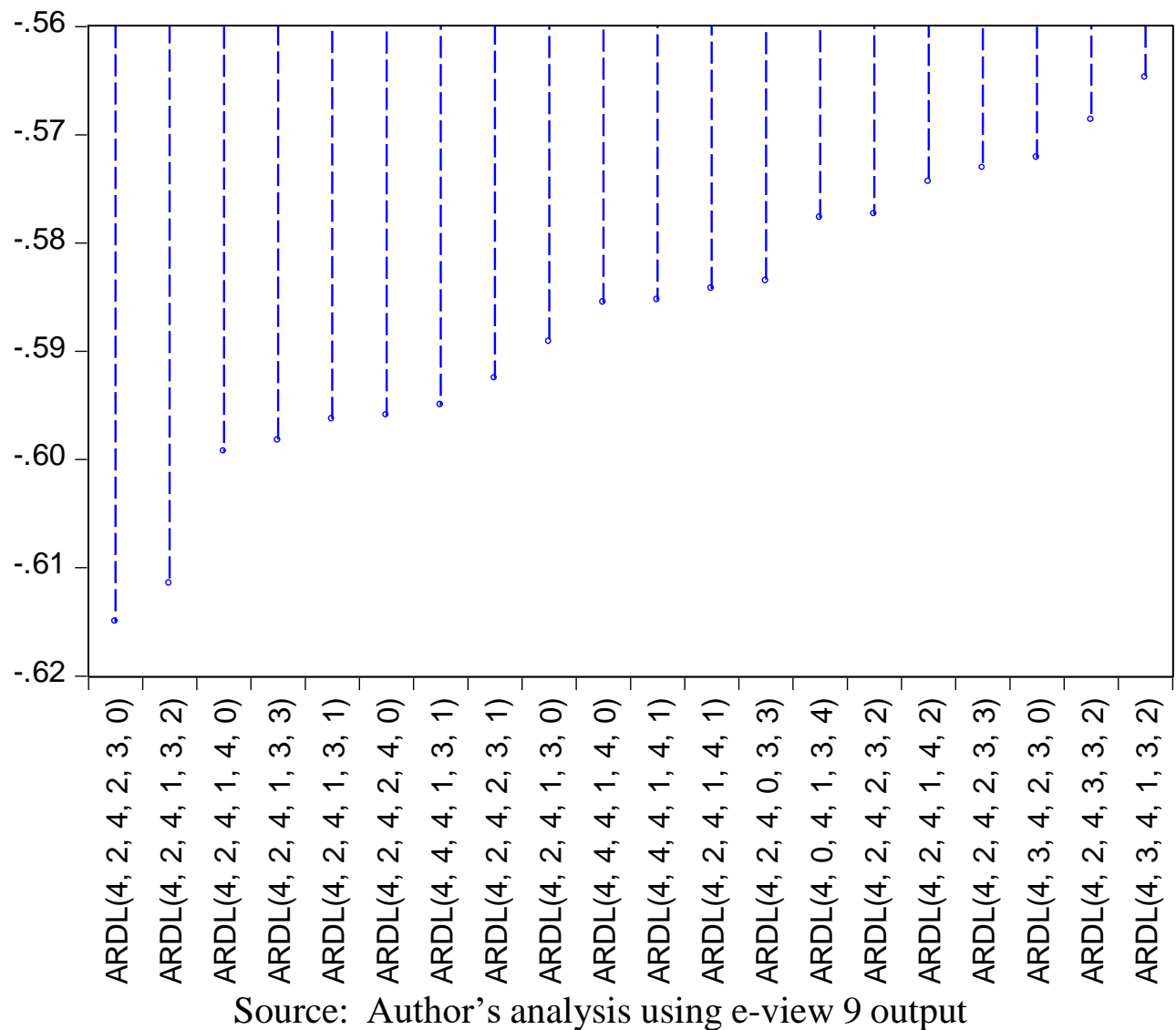

The figure above reveals the top 20 models. It reveals the best model selected by ARDL Model analysis as being (4, 2, $4,2,3$, and 0 ) and interpreted in table 3 above. This was done in order to further proof the validity and reliability of the selected model.

\subsection{Diagnostic Test}

\section{Test for Heteroskedasticity}

Table 4: Heteroskedasticity Test: Breusch-Pagan-Godfrey

\begin{tabular}{llll}
\hline \hline F-statistic & 0.716318 & Prob. F(20,13) & 0.7562 \\
Obs*R-squared & 17.82514 & Prob. Chi-Square(20) & 0.5989 \\
Scaled explained SS & 2.841517 & Prob. Chi-Square(20) & 1.0000 \\
\hline \hline
\end{tabular}

Source: Author's analysis using e-view 9 output

The Heteroskedasticity test above suggests that the variables are free from the problem of Heteroskedasticity since the p-values of F-stat. and Obs*R-squared are $>5 \%$ significance level. This outcome is further strengthened by the pvalue of approximately 1.00 for the Scaled explained SS which also suggest the absence of Heteroskedasticity 


\subsection{Test of Normality}

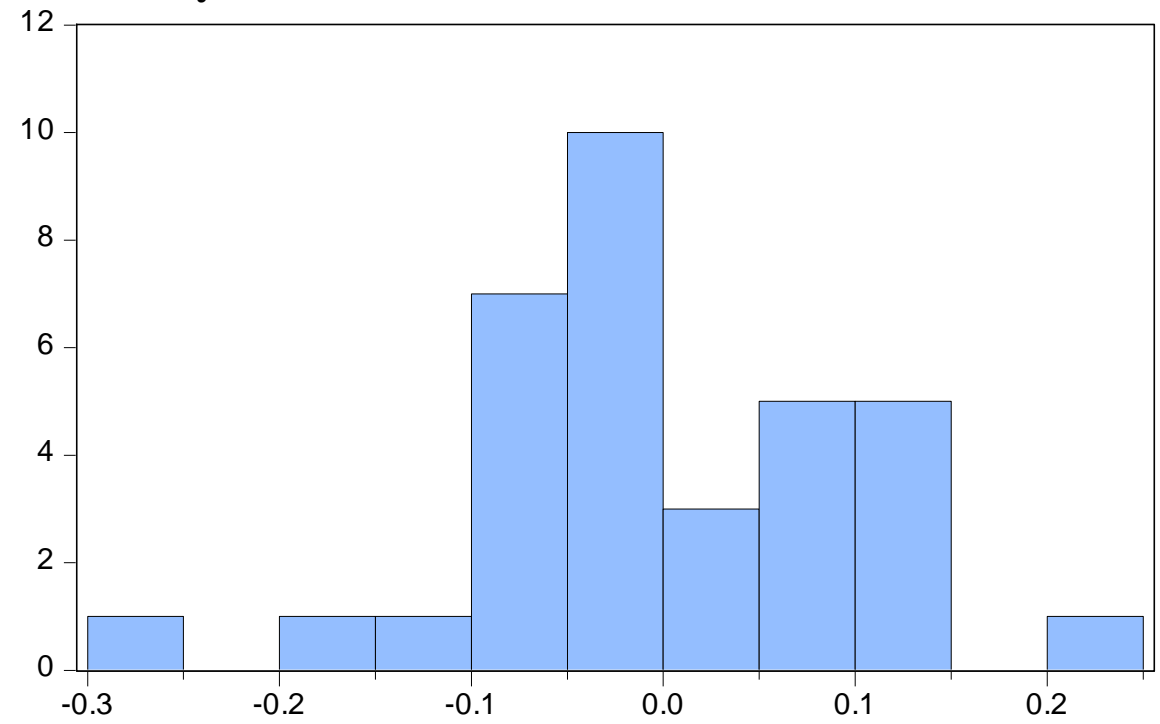

Series: Residuals

Sample 19852018

Observations 34

Mean

$4.92 \mathrm{e}-16$

Median

$-0.013735$

Maximum

0.213287

Minimum $\quad-0.256280$

Std. Dev. $\quad 0.097378$

Skewness $\quad-0.166051$

Kurtosis

3.180813

Jarque-Bera $\quad 0.202562$

Probability $\quad 0.903679$

Figure 2: Normality Test

Source: Author's analysis using e-view 9 output

This test is conducted to ensure that the data employed in this study are normally distributed. Observing from the normality diagram in the figure above, as well as the Jarque-Bera value of 0.20 and its corresponding p-value of $90 \%$ which is $>5 \%$ significant level confirms that the data are normally distributed.

\subsection{Test for Auto Correlation}

Table 5: Correlogram Q-statistic

Q-statistic probabilities adjusted for 4 dynamic regressors

\begin{tabular}{|c|c|c|c|c|c|c|}
\hline Autocorrelation & Partial Correlation & & $\mathrm{AC}$ & PAC & Q-Stat & Prob* \\
\hline.$* 1$. & .*1. & 1 & -0.129 & -0.129 & 0.6202 & 0.431 \\
\hline & $*$ & 2 & -0.065 & -0.083 & 0.7834 & 0.676 \\
\hline & $*$ & 3 & -0.065 & -0.087 & 0.9482 & 0.814 \\
\hline$* * * \mid$. & $* * * \mid$. & 4 & -0.386 & -0.427 & 7.0410 & 0.134 \\
\hline . I*. & & 5 & 0.103 & -0.053 & 7.4876 & 0.187 \\
\hline &.$* 1$ & 6 & -0.040 & -0.151 & 7.5560 & 0.272 \\
\hline. & . $*$ & 7 & 0.178 & 0.087 & 8.9940 & 0.253 \\
\hline $.1 *$ & .1. & 8 & 0.122 & -0.011 & 9.6907 & 0.287 \\
\hline .1. & . & 9 & -0.048 & 0.029 & 9.8045 & 0.367 \\
\hline & . & 10 & 0.030 & 0.022 & 9.8511 & 0.454 \\
\hline & & 11 & -0.142 & 0.001 & 10.929 & 0.449 \\
\hline$*$ & $* * \mid$. & 12 & -0.194 & -0.223 & 13.022 & 0.367 \\
\hline .1. & ** . & 13 & 0.022 & -0.071 & 13.050 & 0.444 \\
\hline . $*$ & & 14 & 0.117 & 0.051 & 13.894 & 0.458 \\
\hline .1. & ***. & 15 & -0.063 & -0.208 & 14.151 & 0.514 \\
\hline .1. & $*$ & 16 & 0.051 & -0.171 & 14.326 & 0.574 \\
\hline
\end{tabular}

Source: Author's analysis using e-view 9 output

This test is carried out to further test for auto correlation and to consolidate on the result of Durbin Watson Stat in table 3. The result of Correlogram Q-Statistic in table 5 above, suggest that the variables are free from auto correlation, since the correlogram Q- Stat. table indicates that all p-values were $>5 \%$ hence, the conclusion that the model was free from auto correlation. 


\subsection{Test for Serial Correlation}

Table 6: Serial correlation

Breusch-Godfrey Serial Correlation LM Test:

\begin{tabular}{llll}
\hline \hline F-statistic & 0.618007 & Prob. F(2,11) & 0.5567 \\
Obs ${ }^{*}$ R-squared & 3.434491 & Prob. Chi-Square(2) & 0.1796 \\
\hline \hline
\end{tabular}

Source: Author's analysis using e-view 9 output

In line with the rule, the Breusch-Godfrey Serial Correlation LM Test table above shows that the probability values of 0.55 indicates that the variables are free from serial correlation. Also, F-statistic and Obs*R-squared of 0.61 and 3.43 respectively further strengthen the assertion of no serial correlation amongst the variables. The probability values are statistically insignificant at 5\% level of significance. Hence, the null hypothesis that there is serial correlation in the model is rejected. Thus, the model is said to be free from serial correlation.

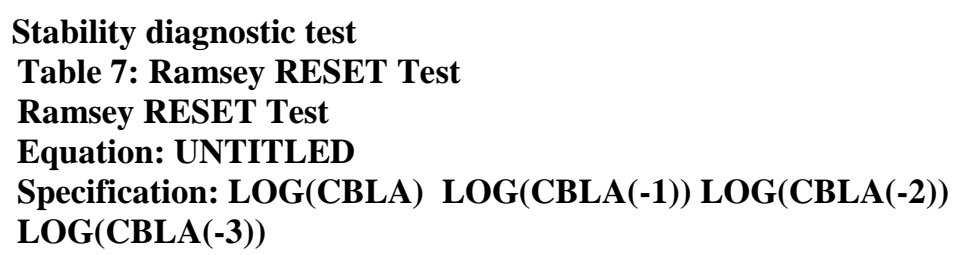

\begin{tabular}{lccc}
\hline \hline & Value & df & Probability \\
\cline { 2 - 4 } t-statistic & 1.652938 & 12 & 0.1242 \\
F-statistic & 2.732203 & $(1,12)$ & 0.1242 \\
\hline \hline
\end{tabular}

Source: Author's analysis using e-view 9 output

From the Ramsey reset test result in table 7 above, the t-statistic of 1.65 and its corresponding p-value of 0.12 suggest that the model is correctly specified, so null hypothesis of linear specification not rejected at $5 \%$ level of significance, since the p-value is $>5 \%$.

\subsection{Test of Hypotheses}

\subsubsection{Test of Hypothesis One}

$\mathrm{HO}_{1}$ : There is no significant impact of interest rate spread on commercial banks' loans and advances in Nigeria.

\begin{tabular}{|ccccc|}
\hline Variable & Coefficient & Std. Error & t-Statistic & Prob. $^{*}$ \\
\hline \hline LOG(CBLA(-4)) & 0.320372 & 0.193278 & 1.657570 & 0.1213 \\
IRS(-2) & 0.063883 & 0.029121 & 2.193713 & 0.0470 \\
\hline
\end{tabular}

Source: Extracted from table 3

Since the p-value for interest rate spread (IRS) of $0.047(4.7 \%)$ is within the acceptable significance level of $5 \%$, that is, $<5 \%$, we fail to accept the null hypothesis that interest rate spread has no significant impact on commercial banks' loans and advances in the Nigerian financial system

\subsubsection{Test of hypothesis two}

$\mathrm{HO}_{2}$ : There is no significant impact of monetary policy rate on commercial banks' loans and advances in Nigeria.

\section{Source: Extracted from table 3}

\begin{tabular}{|crrrc|}
\hline Variable & Coefficient & Std. Error & t-Statistic & Prob. $^{*}$ \\
\hline \hline LOG(CBLA(-4)) & 0.320372 & 0.193278 & 1.657570 & 0.1213 \\
MPR(-4) & 0.037255 & 0.011624 & 3.204950 & 0.0069 \\
\hline
\end{tabular}

Since the p-value for monetary policy rate (MPR) of $0.0069(0.069 \%)$ is within the acceptable significance level of $5 \%$, that is, $<5 \%$, we fail to accept the null hypothesis that monetary policy rate has no significant impact on 
commercial banks' loans and advances in the Nigerian financial system.

\subsubsection{Test of Hypothesis Three}

$\mathrm{H}_{3}$ : There is no significant impact of statutory reserve on commercial banks' loans and advances in Nigeria.

\begin{tabular}{|crrrr|}
\hline Variable & Coefficient & Std. Error & t-Statistic & Prob. \\
\hline \hline LOG(CBLA(-4)) & 0.320372 & 0.193278 & 1.657570 & 0.1213 \\
LR(-2) & -0.007669 & 0.007154 & -1.071918 & 0.3033 \\
\hline
\end{tabular}

Source: Extracted from table 3

Since the p-value for lending rate (LR) of $0.30(30 \%)$ is $>5 \%$ level of significance, the null hypothesis that statutory reserve has no significant impact on commercial banks' loans and advances in the Nigerian financial system is not rejected.

\subsubsection{Test of Hypothesis Four}

$\mathrm{H}_{4}$ : Inflation rate has no significant impact on commercial banks' loans and advances in the Nigerian financial system.

Source: Extracted from table 3

\begin{tabular}{|crrrr|}
\hline Variable & Coefficient & Std. Error & t-Statistic & Prob.* $^{*}$ \\
\hline \hline LOG(CBLA(-4)) & 0.320372 & 0.193278 & 1.657570 & 0.1213 \\
IFR(-3) & -0.010299 & 0.003857 & -2.670071 & 0.0193 \\
\hline
\end{tabular}

Since the p-value for inflation rate (IFR) of $0.0193(1.93 \%)$ is within the significance acceptable level of $5 \%$, that is, < $5 \%$, we fail to accept the null hypothesis that inflation rate has no significant impact on commercial banks' loans and advances in the Nigerian financial system.

\subsubsection{Test of Hypothesis Five}

$\mathrm{H}_{5}$ : There is no significant impact of exchange rate on commercial banks' loans and advances in Nigeria.

Source: Extracted from table 3

\begin{tabular}{|crrrr|}
\hline Variable & Coefficient & Std. Error & t-Statistic & Prob. \\
\hline \hline LOG(CBLA(-4)) & 0.320372 & 0.193278 & 1.657570 & 0.1213 \\
EXR & -0.001053 & 0.001117 & -0.942444 & 0.3632 \\
\hline
\end{tabular}

Since the p-value for exchange rate (EXR) of $0.36(36 \%)$ is $>5 \%$ level of significance, the null hypothesis that exchange rate has no significant impact on commercial banks' loans and advances in the Nigerian financial system is not rejected.

\begin{tabular}{llll} 
& \multicolumn{2}{c}{ Table 8: A priori expectation verification } & \\
Variables & Expected Signs & Actual Signs & Remark \\
IRS & Negative ( - & Positive ( + ) & Do not conform \\
MPR & Negative ( - ) & Positive ( + ) & Do not conform \\
\hline LR & Negative ( - ) & Negative ( - ) & Conform \\
\hline IFR & Negative ( - ) & Negative ( - ) & Conform \\
\hline EXR & Negative ( - ) & Negative ( - ) & Conform \\
\hline
\end{tabular}

\section{Summary of Findings}

The following findings were deduced from the results of the analysis above:

1. Interest rate was found to have a positive and significant impact on commercial banks' loans and advances in Nigeria. This could be as a result of the effectiveness and efficiency of the Nigerian financial system in financial intermediation; depositors are paid the highest return possible for their deposits, while investors are provided credit facilities for the least cost possible, which made interest rate spread fair and moderate for investors to keep taking loans and advances of commercial banks in Nigeria. This assertion is in support of the postulations of Quadal, 2007 who advocated for an efficient intermediation process owing to a moderate interest rate spread charged by commercial banks. 
2. Monetary policy rate was also found to have a significant positive impact on commercial banks' loans and advances in Nigeria; this could possibly be attributed to stability of the Nigerian financial system and the effectiveness of the regulatory institutions in terms of fixing a moderate monetary policy rate that the market responds positive to.

3. Liquidity ratio recorded a negative and insignificant impact on commercial banks' loans and advances in Nigeria. This result was in consonance with A priori expectation, since a huge amount of funds (deposits) that was supposed to be given out as loans by commercial banks are required by law to be kept in the banks' vault as stored liquidity of the banks; this reduces the banks' prowess of making new money.

4. Inflation rate recorded a negative and significant impact on commercial banks' loans and advances in Nigeria, supporting A priori expectation that high inflation would discourage borrowings from commercial banks in Nigeria.

5. Exchange rate recorded a negative yet insignificant impact on commercial banks' loans and advances in Nigeria, the possible reason for the insignificance of exchange rate on commercial banks' loans and advances in Nigeria may be because of the fact that commercial banks in Nigeria did not really engage much in international transactions enough to be really influenced by exchange rate even though a negative impact was recorded.

\section{Conclusion}

In summary, this study was carried out to ascertain the impact of interest tare spread on commercial banks' loans and advances in Nigeria between 1981 and 2018. Auto-regressive Distributed Lag ARDL Model was employed and several diagnostic tests were carried out and all pointed towards the same conclusion that interest ate spread was significant in impacting positively on commercial banks' loans and advances in Nigeria within the period under review.

\section{Recommendations}

From the foregoing, this study proffers the following recommendation:

1. Commercial banks in Nigeria should maintain their current interest rate spread strategy, since its working well for them and helping them realize a high demand for their loans and advances in Nigeria.

2. The monetary authorities in Nigeria should also maintain the level of monetary policy rate charged to the commercial banks in Nigeria in order to allow the commercial banks fix a moderate and competitive interest rate spread.

3. The Central Bank of Nigeria should continue ensuring that commercial banks maintain adequate liquidity in consonance with the statutory reserve requirement of the monetary authorities.

4. The monetary authorities in Nigeria should put economic mechanisms in place to fight and curb high inflation, since high inflation reduces the volume of commercial banks' loans and advances in Nigeria.

5. Proper exchange rate policies have to be formulated and implemented by the Central Bank of Nigeria to check excessive high exchange rate between the Naira and the US Dollar.

\section{References}

Akmal S, Khalid L, Muhammad A (2012). Determinants of Interest Rate Spread: An Empirical Explanation Actual Problems Of Economiics, 2(4): 46-52.

Arezoo G, Malihe R (2016). Determinants of Interest Rate Spread in Banking Industry. Ecoforum, 5(1): 8-18.

Central Bank of Nigeria. (2018). Statistical bulletin,Central bank of Nigeria.

Doliente JS (2005). Determinants of bank net interest margins in Southeast Asia. Applied Financial Economics Letters 1(1): 53-57.

Felix E, Ihuoma E, Odim I (2015). Interest Rate and Commercial Banks' Lending Operations In Nigeria: A Structural Break Analysis Using Chow Test. Global Journal Of Social Sciences 14 (2): 9-22.

International Monetary Fund. (2018). International Monetary Fund, International Financial Statistics and data files 
Maureen W, Joseph W (2014). What Factors Drive Interest Rate Spread of Commercial Banks? Empirical Evidence from Kenya, Review of Development Finance, 4, 73-82.

Muine S, Essau K (2012). Determinants of Commercial Banks' Interest Rate Spread in Namibia:An Econometric Exploration, Botswana Journal of Economics, 4(1): 1-10.

Nazarian R, Hashemi A (2010). Factors affecting the interest rates on the profit, Journal of Economic Sciences, 1(3): 131-149.

Quaden G (2004). Efficiency and stability in an evolving financial system // www.bnb.be/Sg/En/ Contact/pdf/2004/sp040517en.pdf.

Varaidzo S, Asrat T (2018). The impact of interest rate spread on the banking system efficiency in South Africa. Cogent Economics and Finance, 6(1):1-11. 